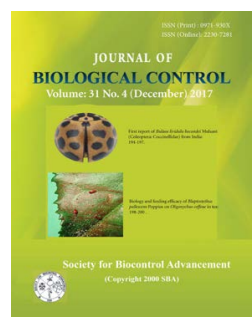

\title{
Bombyx mori nucleopolyhedrovirus (BmBPV): Its impact on silkworm rearing and management strategies
}

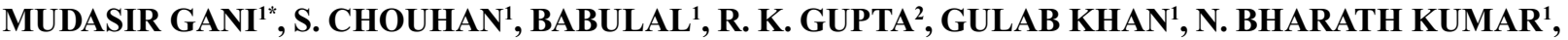 \\ PAWAN SAINI ${ }^{1}$ and M. K. GHOSH ${ }^{1}$ \\ ${ }^{1}$ Silkworm Pathology Laboratory, Central Sericultural Research \& Training Institute, Central Silk Board, Ministry of \\ Textiles, Government of India, Pampore - 192121, Jammu \& Kashmir, India \\ ${ }^{2}$ Biocontrol Laboratory, Division of Entomology, Sher-e-Kashmir University of Agricultural Sciences and Technology- \\ Jammu, Chatha - 180009, Jammu \& Kashmir, India \\ ${ }^{*}$ Corresponding author E-mail: mudasir32@gmail.com
}

\begin{abstract}
The mulberry silkworm Bombyx mori (L.) (Lepidoptera: Bombycidae) is infected with a baculovirus, Bombyx mori nucleopolyhedrovirus (BmNPV) that causes grasserie disease in silkworm and major economic losses to the silk industry. In India, $>50 \%$ of silk cocoon crop losses are attributed to BmNPV infection. Presently, there are no specific preventive measures for the occurrence and spread of BmNPV infection other than sanitized rearing methods, the only commercial practice today is to discard large stocks of worms in case of infection. Although diagnostic kits for detection of BmNPV have been developed, they are not extensively used on a commercial scale and subsequently, they fail to provide the indispensable and timely advantages desired for early disease intervention. The best emerging technology is the use of antibody-based biosensors and lateral flow assays, which have high specificity, sensitivity and the option of "onsite" pathogen detection. The use of disease resistant silkworm breeds or the utilization of inherent resistance in silkworm would be the most economical and effective way to prevent the occurrence of grasserie disease. Further, there is a great need to comprehensively analyze the host genes response to BmNPV infection and its functional analysis to prevent virus replication and its horizontal transmission.
\end{abstract}

KEY WORDS: Antibody, biosensor, Bombyx mori, lateral flow assay, management, nucleopolyhedrovirus

(Article chronicle: Received: 14-07-2017; Revised: 26-09-2017; Accepted: 30.11.2017)

\section{INTRODUCTION}

The mulberry silkworm, Bombyx mori (Linnaeus) (Lepidoptera: Bombycidae) is an economically important insect domesticated for silk production. There are more than 3000 strains of B. mori (Yamamoto, 2000), which are maintained/preserved in germplasm banks around the world. Over $85 \%$ of the global silk production comes from the mulberry silkworm, B. mori. India is a unique country producing all the four known varieties of silk, namely, domesticated mulberry silk (B. mori L.) $(74.50 \%)$, semi-domesticated Eri silk (Philosamia ricini Hutt.) $(16.50 \%)$, wild Tasar silk (Antheraea mylitta Drury) (8.50\%) and exclusive Muga silk (Antheraea assamensis Helfer) (0.6\%). In India, the silk industry has made significant progress during the past two decades and India occupies the second position in global silk production next to China. As per recent statis- tics, India has 82 lakh farmers in 62,000 villages engaged in sericulture and Indian raw silk production is 28,708 metric tonnes (Annual Report, 2014-15, Central Silk Board). The Central Silk Board has set a target of 60,000 metric tonnes of raw silk production by 2030. In view of the demand, the Silk industry is expanding rapidly in India and several other countries. However, in India the raw silk production per hectare is about $97.27 \mathrm{~kg}$, which is low when compared to the sericulturally advanced countries (Jayaramaiah et al., 1986). One of the reasons attributed to low silk production per hectare of mulberry in India is due to frequent crop failures owing to silkworm diseases.

The silkworms are more sensitive to environmental, nutritional and microbial factors, resulting in various diseases leading to silkworm mortality and cocoon crop loss all through the year. The most prevalent and serious dis- 
eases in the silkworm are grasserie, flacherie, muscardine and pebrine caused by virus, bacteria, fungi and microsporidia, respectively (Jiang and Xia, 2014; Babu et al., 2009). A number of viruses, including Nucleopolyhedrovirus (NPV), Infectious Flacherie Virus (IFV), Densovirus (DNV) and Cypovirus (CPV) are known to infect the $B$. mori. They also cause disease in association with one or other viruses and bacteria. Bacteria such as Streptococcus faecalis, S. faecium, Staphylococci sp. and Serratia marcescens cause bacterial flacherie individually or in combination with viruses such as IFV and DNV (Nataraju et al., 1999). Among the viral diseases, nuclear polyhedrosis is most severe and contagious. It can affect $B$. mori in different stages of its life cycle that could lead to serious damage and significant financial losses, thus posing a serious threat to the global sericulture (Sengupta et al., 1990; Brancalhao, 2002). In India, the cocoon crop loss due to diseases was reported as 15-20\% (Balavenkatasubbaiah et al., 2015). Viral diseases account for almost $70 \%$ of the total loss due to diseases (Babu et al., 2009).

\section{Impact of BmNPV on silkworm}

The Bombyx mori nucleopolyhedrovirus (BmNPV) (Family: Baculoviridae; Genus: Alphabaculovirus) causing grasserie disease in silkworm is the most harmful virus in the sericulture industry, often causing severe economic losses (Ponnuvel et al., 2003, Babu et al., 2009). In India, $>50 \%$ of silk cocoon crop losses are attributed to BmNPV infection (Khurad et al., 2006) and in Kashmir valley the silkworm crop losses due to BmNPV are about 28-32\% (Irfan and Nataraju, 2007). The grasserie disease occurs when the silkworms feed on mulberry leaves contaminated with BmNPV (Jiang and Xia, 2014). The Occlusion Bodies (OBs) are the infectious unit of the NPV which are proteinaceous structures that contain the virions (virus particles) and is critical for spreading infection between hosts. The silkworm appears normal and shows no symptoms during more than $2 / 3$ of incubation period. Usually the first symptoms appear 5-7 days post infection. The symptoms of the disease include initial shining of the skin and with the progress of infection, skin becomes fragile with swollen inter-segmental regions and the haemolymph appears milky white. At the time of death most of the organs are observed to have degenerated and liquefied. The diseased larvae sometimes remain hanging head downwards with its claws. Silkworm pupae and the moth develops no specific morphological changes during the greater part of the incubation period. But, by the end of the disease cycle, the integument become fragile and easily ruptures releasing the liquefied tissues of pupa (Nataraju et al., 2005). With the death of host, larval body tissue is converted into millions of OBs that are released into the environment. The dead diseased pupae and moth also release the infectious OBs. These OBs contaminates the silkworm-rearing environment, the rearing house; appliances etc. and serve as a source of infection for healthy silkworms. The microscopic observation of a drop of haemolymph from diseased larvae reveals the presence of large number of hexagonal/pentagonal or tetragonal structures - the OBs/polyhedra.

\section{BmNPV detection techniques}

The BmNPV detection is needed to stop spread of the disease in rearing units, to take suitable preventive steps, to initiate appropriate control measures and for certification in National and International trade. The grasserie disease epidemics are driven by the amount of initial inoculum and the rate of transmission, it is essential to have diagnostic procedures which allow rapid detection of initial inoculum. The level at which the disease becomes apparent depends to a large extent on the ability of the observer to recognise the disease. Many times the disease remains undetected (latent, sub-lethal) and is only recognised once the disease had reached the epidemic levels (lethal). Once the symptoms of disease appear, it is too late to apply control measures. Obviously, absence of visible disease symptoms does not necessarily indicate absence of pathogen or freedom from pathogen-induced mortality. It is necessary therefore for insect pathologists to emphasize on generating sensitive and portable assays capable of rapid diagnosis to avoid the possibility of disease epidemics in silkworm rearing.

The present most common methodologies for BmNPV detection include microscopy, in vivo assays and nucleic acid based analysis (Joshi and Raja, 2016). Other techniques that have been developed to detect BmNPV include Enzyme-Link Immunosorbent Assay (ELISA) (Vanapruk et al., 1992), DNA hybridization (Attathom et al., 1994), colloidal textile dye-based dipstick immunoassay (Nataraju et al., 1994), protein-A linked monoclonal antibody latex agglutination test (PALMAL) (Shamim et al., 1995) and viral DNA transfection (Martinex-Zubiaur et al., 2016). The implementation of nucleic acid based analyses by Polymerase-Chain Reaction (PCR) and sequencing for BmNPV detection can be complicated by external factors. For example, original stock inoculum that often contain high levels of fats, carbohydrates and other entities which necessitate a sample clean-up stage prior to analysis. Non-specific DNA amplification may also be observed; the presence of 'naked' DNA in analytical samples may act as a template for the amplification of these superfluous products which complicates fingerprint-based analysis. All these methods stated above require isolation of the pathogen, nucleic acid extraction, skilled person and equipment, costly and are difficult to perform as routine assays. The possibilities of 
variations induced by the personnel, transportation of samples, processing and the testing conditions and the lack of uniform analytical platforms further complicate the process making the data unreliable. In addition, these assays lack the convenience of "on-site" testing and require a complex work flow starting from sample collection, sample labelling, sample storage and transport to appropriate facility, followed by further sample processing, after which the samples are assayed and the results are interpreted. Hence, developing suitable detection methods which permit accurate, rapid and sensitive analysis is essential for silkworm disease management. The best emerging technology is the use of biosensors and Lateral Flow Assay (LFA) that provide us with a tool to rapidly detect the presence and amount of pathogen in any given environment.

A biosensor is actually a compact analytical device with a ligand-specific biorecognition element (antibody, enzyme, receptor, nucleic acid, aptamers, peptide/protein, lectin, cells, tissue or whole organisms) immobilized on a sensor surface integrated directly or indirectly with a signal conversion unit called a transducer. The physiological interaction between the ligand and the biorecognition element is translated, by the transducer, into a measurable electric signal, which is further deciphered by a computer-aided readout system for the user (Arora et al., 2010). Biosensors are chiefly classified based on the biorecognition element and the transducers. Antibody-based biosensors employ antibody as biorecognition element and are well suited for development of point-of-care-and "on-site" diagnostics (Conroy et al., 2009). Essentially the selectivity or specificity of the biosensor is dependent on the bio recognition element which is capable of sensing the presence of an analyte. The transducer element translates the selective recognition of the analyte into a quantifiable signal and thus, has a major influence on the sensitivity.

The Lateral Flow Assay (LFA) is a paper-based platform for the detection and quantification of analytes in complex mixtures, where the sample is placed on a test device and the results are displayed within 5-30 min. LFAs are very good candidates for disease detection as they are cheap to produce, easy to use and widely accepted by users (Koczula and Gallotta, 2016). Moreover, because of the long shelf life and the fact that refrigeration is not required for their storage, LFAs are very well suited for field use. LFAs are categorized into 'Lateral Flow Immunoassays' (LFIAs), in which antibodies are exclusively used as recognition elements and Nucleic Acid LFA (NALFA) which are used for the detection of amplicons formed during the polymerase chain reaction (PCR) (Connelly et al., 2008).
Both these techniques can be effectively performed outside the laboratory and are well suited for development of "on-site" diagnostics. They are easy to use and do not require trained personnel, laboratory equipment or reagents, thus, capable of testing and yielding results on site, cutting short the lengthy process. As of yet, there is no report of the application of antibody-based biosensor or lateral flow assays in B. mori NPV detection or any other silkworm pathogen.

\section{Management strategies}

Grasserie disease caused by BmNPV is very difficult to manage due to a very short life cycle of silkworm. Presently, there are no curative measures against this tough disease and practice of hygiene through effective disinfection of rearing house is recommended. Also recommended are the prophylactic measures to prevent the spread of the disease in the silkworm colony by the application of bed disinfectant. Although the disinfection of silkworm rearing environment and application of bed disinfectant is expected to maintain the pathogen load to the significant tolerable level, it may not be always adequate to prevent the diseases occurrence. Prevention is better than cure is the correct approach that should be adopted in integrated silkworm disease management. Care is also needed to be taken to see that the silkworms are not exposed to stress conditions like temperature, humidity, bad ventilation, feeding arrest, parasitism and nutritional deficiency which may make them easily susceptible to grasserie disease (Kobayashi et al., 1981). Dependence on treatment after the disease appearance will always entail losses. In short, the fundamental basis of silkworm disease management is the constant implementation of the policy of prevention first. Under this policy, strict disinfection to eliminate risk of diseases transmission and increasing the vigour of the silkworms to enhance resistance to diseases are given due weight age. Sanitation before, during and after each rearing should be carried out effectively and strictly. Therefore, it is essential to have a better estimation of silkworms susceptibility to BmNPV based on genetic and environmental factors and to decide on the most effective intervention steps for disease prevention and treatment.

The use of disease resistant silkworm breeds or the utilization of inherent resistance in silkworm would be the most economical and effective way to prevent the occurrence of grasserie disease. The Indian silkworm germplasm bank has rich indigenous and exotic breeds and some of them are known for strong resistance to viral pathogens (Lekha et al., 2015). The productive breeds are comparatively more susceptible to diseases in general and particularly to the BmNPV. However, it is possible to exploit the 
germplasm to develop BmNPV resistant and productive breeds thereby enhancing overall cocoon productivity.

Though BmNPV was the first described NPV, the genome of the BmNPV was completely sequenced and analyzed in 1999. However, at least two third of the BmNPV viral gene functions are still unknown (Yang and Zhang, 2012). The genome-wide association studies (in which the frequency of genetic variants is compared between infected and healthy controls or between susceptible and resistant individuals) have revolutionized the search for genetic risk variants underlying diseases. It has clearly marked the beginning of a new era to gain a better understanding of disease etiology or identifying the disease-causing genes. Therefore, there is a great need to comprehensively analyze the host genes response to BmNPV infection to identify the true causal gene and its functional analysis to prevent virus replication and its horizontal transmission. These studies are expected to have a significant impact on the development of appropriate BmNPV diagnostic tools and therapeutics.

\section{CONCLUSION}

The grasserie disease caused by BmNPV is one of the major setbacks to sericulture that affects $B$. mori in different stages of its life cycle leading to significant financial losses at the farmers' level. The prevention and treatment of grasserie disease is still largely ineffective and the full understanding of the genetic and host factors is still not clear. One of the most effective solutions is timely detection of BmNPV infection in silkworm rearing to stop further spread of the disease. The most advanced disease diagnosis technique is the use of antibody-based biosensors and lateral flow assays which exhibit high sensitivity and specificity and thus, can serve as good detectors of BmNPV with unprocessed or crude samples. Improving silkworm's resistance to BmNPV is the only viable option to reduce the economic losses caused by this tough disease and promote the healthy development of sericulture. At the same time, identification of grasserie disease-predisposing factors and functional analysis on candidate genes will yield better insights towards the development of new therapeutics. This will help in the restoration of sericulture output and will safe guard the interest of the farmers involved in sericultural practices.

\section{ACKNOWLEDGEMENTS}

The authors are grateful to Dr. V. Sivaprasad, Director, CSR\&TI, Mysore, Karnataka and Dr. Mohd. Ayoub Qadri, Scientist, National Institute of Immunology, New Delhi, for suggestions and guidance during the preparation of this review article.

\section{REFERENCES}

Annual Report, 2014 -15, Central Silk Board, Ministry of Textiles, Government of India. http://www.csb.gov.in/ assets/Uploads/pdf-files/CSBAR-1415English.pdf

Arora S, Pastorella G, Byrne B, Marsili E, O'Kennedy R. 2010. Microbial cells and biosensing: A dual approach-exploiting antibodies and microbial cells as analytical/power systems, pp. 63-75. In: Zacharis, C.K., Tzanavaras, P.D. (Eds.). Reviews in Pharmaceutical and Biomedical Analysis, Bentham Science Publishers, Sharjah, UAE.

Attathom T, Attathom S, Kumpratueang S, Audtho M. 1994. Early detection of Grasserie disease of silkworm, Bombyx mori by DNA probe, pp. 257-271. In: Proceeding of 32nd Kasetsart University Annual Conference: Plant Science, Kasetsart University, Bangkok, Thailand.

Babu KR, Ramakrishna S, Reddy YHK, Lakshmi G, Naidu NV, Basha SS, Bhaskar M. 2009. Metabolic alterations and molecular mechanism in silkworm larvae during viral infection: A review. African J Biotech. 8(6): 899907. DOI: $10.5897 /$ AJB2009.000-9149

Balavenkatasubbaiah M, Sharma SD, Chandrasekharan, K, Narasimha Nayaka AR, Sivaprasad V. 2015. Silkworm disease management technology for higher cocoon productivity and crop stability - a success story. Int $J$ Res in Zool. 5(1): 1-4. https://www.urpjournals.com/ tocjnls/46_15v5i1_1.pdf

Brancalhao RMC. 2002. Vírus entomopatogenicos no bicho-da-seda: Taxonomia e citopatologia causada por nucleopolyhedrovirus em celulas de Bombyx mori. Biotecnologia Ciencia e Desenvolvimento. 24: 54-58.

Connelly JT, Nugen SR, Borejsza-Wysocki W, Durst RA, Montagna RA, Baeumner AJ. (2008). Human pathogenic Cryptosporidium species bioanalytical detection method with single oocyst detection capability. Anal Bioanal Chem. 391: 487-495. doi:10.1007/s00216008-1967-2. Crossref.

Conroy PJ, Hearty S, Leonard P, O’Kennedy RJ. 2009. Antibody production, design and use for biosensorbased applications. Semin Cell Dev Biol. 20: 10-26. DOI: $10.1016 /$ j.semcdb.2009.01.010. Crossref. 
Illahi I, Nataraju B. 2007. Prevalence of nuclear polyhedrosis in mulberry silkworm, Bombyx mori L. in Jammu and Kashmir. Indian J Seric. 46(1): 43-48.

Jayaramaiah M, Kubrerappa GC, Devaiah MC, Kotikal Y. 1986. White muscardine disease of silkworm and its management. Indian Silk 25(8): 15-16.

Jiang L, Xia QY. 2014. The progress and future of enhancing antiviral capacity by transgenic technology in the silkworm Bombyx mori. Insect Biochem Mol Biol. 48: 1-7. Crossref.

Joshi RP, Raja IA. 2016. Polymerase chain reaction based detection of Grasserie virus, BmNPV in Silkworm, Bombyx mori. Biosci Biotech Res Comm. 9(3): 471474. http://www.bbrc.in/bbrc/2016july-sepPDF/ BBRC8_019.pdf

Khurad AM, Kanginakudru S, Qureshi SO, Rathod MK, Rai MM. 2006. A new Bombyx mori larval ovarian cell line highly susceptible to nucleopolyhedrovirus. J Invertebr Pathol. 92: 59-65. http://www.cdfd.org.in/images/ JNRPDF/jip.pdf. Crossref. PMid:16713602

Kobayashi M, Inagaki S, Kawase S. 1981. Effect of high temperature on the development of nuclear polyhedrosis virus in silkworm Bombyx mori. J Invertebr Pathol. 38(3): 386-394. Crossref.

Koczula KM, Gallotta A. 2016. Lateral flow assays. Essays in Biochem. 60: 111-120. Crossref.

Lekha G, Gupta T, Awasthi AK, Murthy GN, Trivedy K, Ponnuvel KM. 2015. Genome wide microarray based expression profiles associated with BmNPV resistance and susceptibility in Indian silkworm races of Bombyx mori. Genomics 106(6): 393-403. Crossref.

Martinex-Zubiaur Y, Abreu MP, Hernández MCP, Sihler W, Falcao R, Ribeiro BM, Lobo de Souza M. 2016. First record of a Bombyx mori nucleopolyhedrovirus (Bmnpv) isolate from cuba. J Curr Res. 8: 35766-35770. http:// www.journalcra.com/sites/default/files/16594.pdf

Yang ZN, Zhang CX. 2012. Advances on BmNPV Functional Genomics. J Biotechnol Biomaterial. 9: 1-6.
Nataraju B, Sivaprasad V, Datta K. 1999. Studies on the cause of thatte roga in silkworms, Bombyx mori L. Indian $J$ Seric. 38: 149-151.

Nataraju B, Sivaprasad V, Datta RK, Gupta SK, Shamim M. 1994. Colloidal textile dye-based dipstick immunoassay for the detection of nuclear polyhedrosis virus (BmNPV) of silkworm, Bombyx mori L. J Invertebr Pathol. 63: 135-139. Crossref.

Nataraju B, Subbaiah BH, Sharma SD, Sudhakararav P, Selvakumar T, Chandrasekharan K. 2005. Cost economics of silkworm disease management. Indian Silk 43(9): $8-10$.

Ponnuvel KM, Nakazawa H, Furukawa S, Asaoka A, Ishibashi J, Tanaka H, Yamakawa M. 2003. A lipase isolated from the silkworm Bombyx mori shows antiviral activity against nucleopolyhedrovirus. J Virol. 77: 10725-10729. Crossref.

Sengupta K, Kumar P, Baig M. 1990. Handbook on Pest and Disease Control of Mulberry and Silkworm. Economic and Social Commission for Asia and Pacific, UNESCAP (United Nations Economic and Social Commission for Asia and the Pacific), Bangkok.

Shamim M, Baig M, Nataraju B, Datta RK, Gupta SK. 1995. Evaluation of protein-a linked monoclonal antibody latex agglutination test for diagnosis of nuclear polyhedrosis virus (BmNPV) of silkworm Bombyx mori L. $J$ Immunoass. 16(2): 155-166. Crossref.

Vanapruk P, Attathom T, Sanbatsiri K, Attathom S. 1992. Comparison of methods for the detection of nuclear polyhedrosis virus in silkworm, Bombyx mori Linn. In: Proceedings of the $30^{\text {th }}$ Kasetsart University Annual Conference: Plant Science, Kasetsart University, Bangkok, Thailand, 237-243.

Yamamoto T. 2000. Silkworm Strains, pp. 45-49. In: Nakatsuij, N. (Eds.). Strains Maintenance and Databank for Life Science, Kyoritsu Shuppan, Tokyo. 